\title{
ReVieW ARTiCle: TWo "IMAges of ASiA" A COMPARISON
}

\author{
Jonathan Perry
}

Jennifer Lindsay, Javanese Gamelan, 2nd ed. rev. vii, 76 pp. Published in Singapore by Oxford University Press Pte. Ltd., in the United States by Oxford University Press, Inc., New York, 1992. (Images of Asia)

Ward Keeler, Javanese Shadow Puppets. vii, 72 pp. Published in Singapore by Oxford University Press Pte. Ltd., in the United States by Oxford University Press, Inc., New York, 1992. (Images of Asia)

Jennifer Lindsay and Ward Keeler present images of their genres, to varying degrees both Javanese and Western images. Lindsay takes a historical and descriptive approach, whereas Keeler delves more deeply into social and political implications.

Lindsay wants to preserve the image of gamelan which she gave in the 1979 edition of Javanese Gamelan. As she explains in her Preface, the explanatory chapters of the original edition are retained almost in their entirety, since

the more one studies gamelan, the more difficult it is to step back and write simply about its complex musical concepts (p. v).

Lindsay introduces us to her image by tracing the mythological and historical background of the gamelan, including the simultaneous evolution of two styles of gamelan music-loud and soft. She follows this with a well-illustrated catalogue of gamelan instruments, categorizing them as "phrase-making," "loud," and "soft." The first of two chapters on gamelan theory contains an explanation of the two tuning systems-slendro and pelog-with six resulting modes. In the second, Lindsay explains and illustrates the principles of "layering," "cyclical structure," and "expansion and contraction," upon which the structure of gamelan music is built. She completes her image of gamelan by placing its historical development in relation to that of other performing arts.

Keeler's Javanese Shadow Puppets is one product of the author's 1988 field work, in which he researched the aesthetic principles underlying wayang and the ways in which this genre fits into its cultural setting. Keeler's opening chapter-an eye-witness account of a wayang 
performance with its sights, sounds, and smells-helps the reader begin to imagine the genre in its context. This is followed by an interpretation of wayang's role in Javanese society, in which Keeler stresses its importance in ritual and its significance for the sponsoring family. In his chapter entitled "What Might Wayang Mean?" Keeler examines Javanese views on its ethical and religious significance, and Western theories concerning its origins and significance, thus developing further his image of wayang in its cultural setting.

Performing arts traditions, such as Javanese gamelan and wayang, may be viewed as Benedict Anderson views nations in his Imagined Communities. ${ }^{1}$ Just as historians, nationalist leaders, and the populace can imagine a nation which has never existed, Western ethnomusicologists, Indonesian government officials, and the Javanese populace can imagine art traditions which did not exist in precisely those forms, as little as a century before. For example, Lindsay and Keeler, in their attempts to present Javanese images, have unavoidably mixed in Western images. Government officials, in their efforts to crystalize regional traditions, have promoted certain genres and suppressed others. Javanese artists and scholars, in their search for the true interpretation of their arts, have reached differing conclusions.

Lindsay initially presents a Western image of gamelan, describing gamelan instruments, much as a Western museum guide codifies artifacts, and explaining gamelan theory, without placing it in a Javanese context. In the final chapter, however, she exposes the reader to a Javanese image of the genre: gamelan is always played in conjunction with ceremonies or as accompaniment to traditional dance. The Western image of a "concert tradition" is foreign to the Javanese:

... the idea of people sitting in a large group to listen quietly and attentively to the performance of gamelan was and is a strange notion (p. 62).

This distinction could have been made earlier in the book, and more clearly, by means of illustration, showing the context in which gamelan music is played, for example an account of a Javanese wedding reception. She also explains that learning gamelan is a social activity, rather than the individual endeavor which studying music tends to be in the West (pp. 62, 63). The implications of this social aspect of gamelan need to be developed, for instance the social interplay during rehearsals and the restraints imposed on individuality. Thus, Lindsay points out two profound differences between Western and Javanese images of performed music, but does not amplify them.

Keeler presents a more consistently Javanese image of his genre. In his eyewitness account of the wayang performance, he intersperses observations about the performance atmosphere-conversation, squabbles over seating, gambling, snacking, smoking, and sleepingwith an account of the story "Pandhu Crowned King." To this he adds his observations of the dhalang's many roles-manipulating all the puppets, speaking, chanting or singing all parts in the appropriate level of Javanese, as well as giving directions to the gamelan players. This approach allows the reader to imagine wayang from a Javanese perspective, with a minimum of Western distortion. Even his technical chapters stress the Javanese-ness of the genre; for example, he explains that the dhalang have impressed their unique Javanese stamp on the Indian epics by developing "branch stories" which embellish the original plot.

There is, however, a confusing clash of Western and Javanese images in his chapter on the meaning of wayang. In the section entitled "Javanese Commentaries," he presents several Javanese views on the ethical and religious significance of wayang, which he refutes on the

${ }^{1}$ Benedict R. O'G. Anderson, Imagined Communities (London: Verso, 1983), pp. 15, 19. 
basis of a Western scholar's writings (pp. 59, 60). ${ }^{2}$ Then, in the section "Western Commentaries," he cites late eighteenth- through early twentieth-century theories concerning the origins of wayang, which he counters with Javanese beliefs (pp. 63, 64). It would have been more consistent to evaluate Javanese theories on the basis of Javanese scholarship, and Western theories on the basis of Western scholarship.

The attempt to delineate truly Javanese images of the arts is complicated by two problems: first, that varied and conflicting interpretations of each genre are espoused by Javanese sub-cultures; and, second, that various factions, including the present government, have imagined ways in which these two genres could further their goals. The various interpretations of wayang-magical, mystical, religious, ethical, hierarchical, and didactic-are held by segments of the Javanese population, which could conceivably be characterized according to age, geography, religion, social status, and other factors. The question, therefore, becomes not only whether the image is Javanese or not, but which Javanese subculture conceives a particular image.

The issue of Javanese sub-cultures may be clarified by considering the question of aesthetic preference. Both authors stress the aesthetic pleasure which the genres afford their audiences. Keeler asserts that "more central than any essential 'meaning' is the aesthetic pleasure [wayang] affords its spectators" (p. 65). Lindsay writes that "the learning of gamelan is also the art of learning Javanese aesthetics of beauty and restraint ..." (p. 67). But there is a vast difference of opinion, among Javanese, concerning what constitutes beauty.

Javanese aesthetic criteria have often been determined by the goals of the sponsors. In the past, Javanese aristocracy preferred a loud, bombastic style of gamelan for court ceremonies, as a symbol of royal power, according to Pemberton, whereas the current government favors the quiet style, as a form of opiate, lulling the populace into submission. ${ }^{3}$ In the sixteenth century, Sunan Kalijaga is said to have created a pelog gamelan which had unusually thick keys, capable of producing exceptionally loud sounds, in order to spread Islam throughout Java, because he knew that such a style would be irresistable to the populace. ${ }^{4}$ Djoddy Matsyachir, an East Javanese intellectual, favors East Javanese arts, which he perceives as egalitarian, as opposed to Central Javanese arts, which he considers elitist, inspired by the royal courts. ${ }^{5}$ The result is a variety of aesthetic criteria, producing diverse images of gamelan and wayang, but which are all equally Javanese.

Throughout its recorded history, gamelan and wayang have been put to use by various factions-monarchies, Muslims, Christians, nationalists, Communists, and the New Orderto fulfill their visions. Keeler alludes to the theory that Muslims used wayang to convert the

\footnotetext{
2 Keeler appeals to Anderson's 1965 work, Mythology and the Tolerance of the Javanese, to refute the religious, or ethical interpretation of wayang. Anderson holds the view that the Javanese values, which are taught and confirmed by wayang, are not precisely moral values, and therefore not religious or ethical in the Western sense. These values, rather, concern appropriate behavior for each station in life-whether king, knight, or servant. Benedict R. O'G. Anderson, Mythology and the Tolerance of the Javanese (Ithaca: Cornell University Modern Indonesia Project, 1965), p. 7.

3 John Pemberton, "Musical Politics in Central Java (Or How Not to Listen to a Javanese Gamelan)," Indonesia 44 (October 1987): 23, 24, 29.

4 Warsadinigrat, "Wedha Pradangga," in Karawitan: Source Readings in Javanese Gamelan and Vocal Music, 2 vols., ed. Judith O. Beeker (Ann Arbor: University of Michigan Press, 1984), 2: 55, 57.

${ }^{5}$ Quoted in R. Anderson Sutton, Traditions of Gamelan Music in Java: Musical Pluralism and Regional Identity, Cambridge Studies in Ethnomusicology (Cambridge: Cambridge University Press, 1991), p. 181.
} 
Javanese (p. 64). He also points out that wayang was used by opposing political factions, particularly in the 1950 s and early 1960 s (pp. 64, 65), 6 and by the present government, which pressures dhalang to promote its programs, such as family planning, through comedy scenes (p. 29). He mentions the establishment, in this century, of state-run academies to train dhalang. These academies "claim the authority to establish the proper way to perform" ( $p$. 71). Keeler acknowledges that the academies may influence such aspects of wayang as its length and language, but does not consider the political ramifications.

Lindsay makes no reference to political images or exploitation of the gamelan..$^{7}$ The issue of political imagery, for instance, has been researched by Pemberton, who has observed that certain instruments represent authority figures-the king or prime minister, and, by extension, modern political figures. Because of this imagery, the government promotes the institution of gamelan music at public gatherings, to encourage submission to authority. ${ }^{8}$ Lindsay does mention the growth of performing arts institutes, since the mid-1960s, stating that "they see themselves as setting the standards and maintaining the classical tradition" (pp. 64-67). She also observes that the organizers of gamelan competitions are often graduates of these institutes (p. 65). She does not, however, consider the political influence which can be exerted by the institutes and the competitions.

Sutton has researched the issue of government control over regional gamelan traditions, concluding that this control is exercised through various channels: performing arts institutes, festivals, competitions, and seminars (penataran, literally "upgradings"). The stated objective of these endeavors is the "definition and crystallization of regional traditions," whereas the real intention of the government is "the curbing of any political potency these genres might have." 10 As the authorities attempt to define regional traditions, they promote certain genres and suppress others, and they often impose the style of one region on another. In this way, therefore, regional images of the arts are being invented which did not exist in those forms less than a century before.

Through the above channels, the government communicates to performers that their images of gamelan and wayang are not valid and must be made to conform to the official images. Interviews conducted by the reviewer, with Javanese scholars who have researched the political role of the arts, indicate that performers, in particular dhalang, feel that their freedom of expression is being increasingly curtailed. The standardization of regional genres and the formulation of aesthetic criteria by the government has taken the "gusto" 11 out of their performances. One Javanese intellectual worries that "pembinaan akan menjadi

${ }^{6}$ An illustration of the use of wayang by a political faction, and the ensuing debate, may be found in Ruth McVey, "The Wayang Controversy in Indonesian Communism," in Content, Meaning and Power in Southeast Asia, ed. Mark Hobart and R. H. Taylor (Ithaca: Cornell University Southeast Asia Program, 1986).

7 Admittedly, the purpose of the series Images of Asia is not to publish scholarly papers; it is rather to enable the non-specialist reader to deepen his understanding and appreciation of Southeast Asia. It is a conscious choice, however, on the part of the writers and publisher, to include or exclude social and political implications of the arts in their images.

8 Pemberton, "Musical Politics," p. 29.

${ }^{9}$ Sutton, Traditions, p. 185. Although this objective is given in connection with the institutes, it applies equally to the other measures.

${ }^{10}$ Ibid., p. 189. Sutton considers this to be the government's intention with regard to competitions, but it applies equally to the other measures.

${ }^{11}$ The English word "gusto," as used by the Javanese interviewee, probably refers to a robust enthusiam on the part of the performers; it would be fascinating to research further, especially its connection with the Indonesian word semangat. 
pembinasaan" (building will become destruction): the government's efforts to improve the arts may result in their extinction. ${ }^{12}$

In summary, Keeler gives a Javanese image of wayang in its cultural setting, with minimal Western distortion. Lindsay's survey reflects a predominately Western viewpoint, but provides valuable insight into a Javanese image of gamelan.

12 The Javanese interviewed will remain anonymous, due to the sensitive nature of the subject. 